\title{
MICROBIAL QUALITY ANALYSIS OF RAW MIXED SALAD VEGETABLES
}

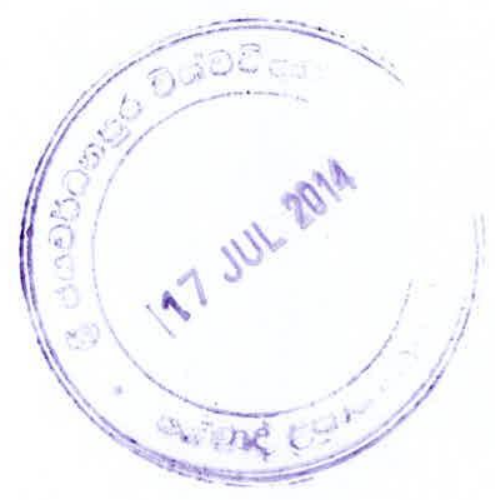

BY

LASANTHA DAMAYANTHIE ABAYNAIKE

This Thesis submitted in partial fulfillment of the requirements for the Degree of Masters of Food Science and Technology,

Department of Food Science and Technology,

Faculty of Applied Science,

University of Sri Jayewardenepura, Sri Lanka 


\section{DECLARATION}

The work described in this thesis was carried by me, under the supervision of Professor K.K.D.S. Ranaweera and the report on this thesis has not been submitted in whole or in part of any University or any other institution for another Degree/ Diploma.

$26-01-2014$

Date

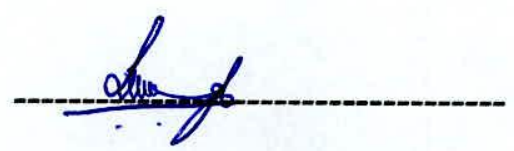

Lasantha D. Abaynaike 
"I certify that the above statement made by the candidate is true and that this thesis is suitable for submission to the university for the purpose of evaluation"

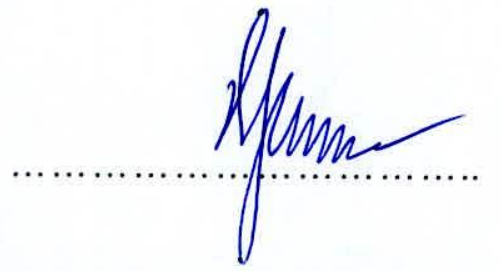

Professor K.K.D.S. Ranaweera

Senior Lecture

Department of Food Science and Technology

University of Sri Jayewardenepura

Director

Bandaranaike Memorial Ayurvedic Research Institute

Nawinna, Maharagama

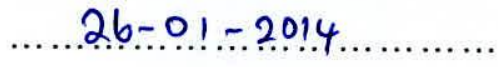

Date 
Dedicated to My Loving Family 


\section{TABLE OF CONTENTS}

Page No

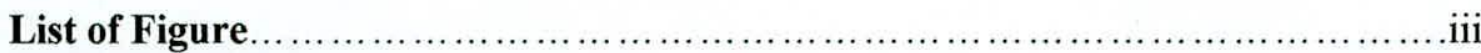

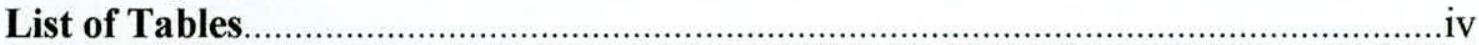

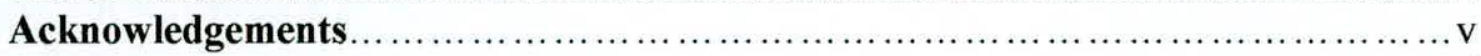

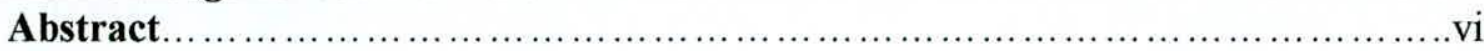

\section{CHAPTER 01}

INTRODUCTION

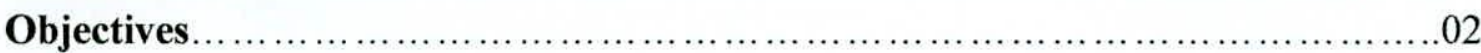

\section{CHAPTER 02}

\section{LITERATURE REVIEW}

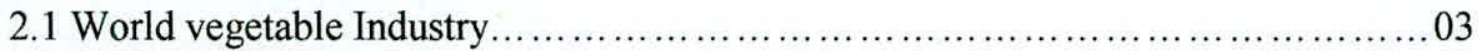

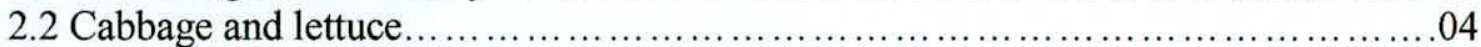

2.2.1 Production chain of cabbage .............................................. 05

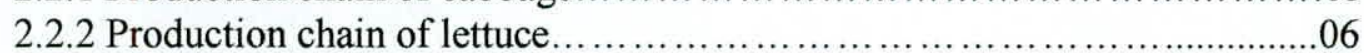

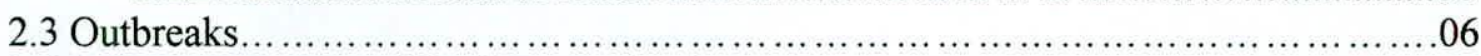

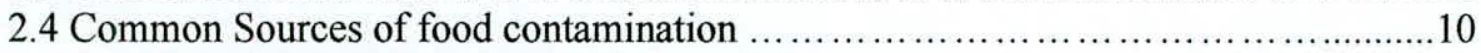

2.5 Sources of microbial contamination in salad vegetables...........................11

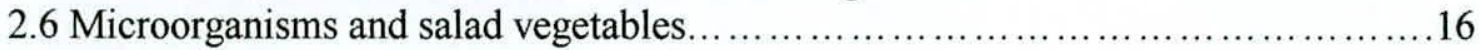

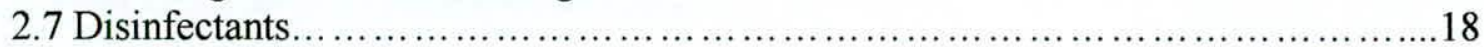

\section{CHAPTER 03}

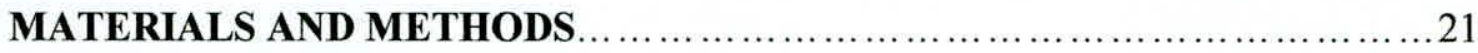

\section{CHAPTER 04}

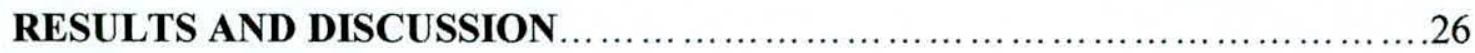

\section{CHAPTER 05}

CONCLUSION 


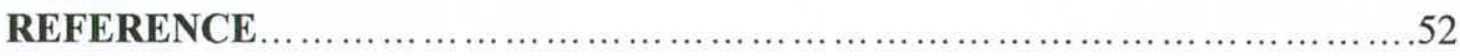

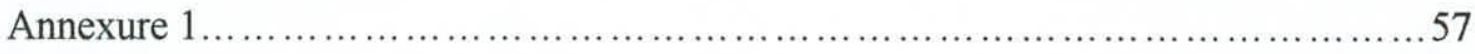

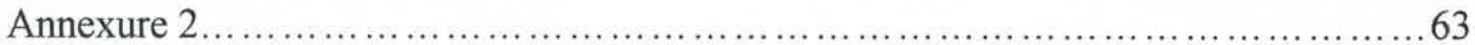




\section{LIST OF FIGURES}

Figure 4.1: APC in lettuce (outer leaves) from two locations

Figure 4.2: Coliform count in lettuce (outer leaves) from two locations

Figure 4.3: E.coli count in lettuce (outer leaves) from two locations

Figure 4.4: Aerobic bacteria count in lettuce (inner leaves) from two locations

Figure 4.5: Coliform count in lettuce (inner leaves) from two locations

Figure 4.6: E.coli count in lettuce (inner leaves) from two locations

Figure 4.7: Aerobic bacteria count in lettuce (mix leaves) from two locations

Figure 4.8: Coliform count in lettuce (mix leaves) from two locations

Figure 4.9: E.coli count in lettuce (mix leaves) from two locations

Figure 4.10: Aerobic bacteria count in cabbage (outer leaves) from two locations

Figure 4.11: Coliform count in cabbage (outer leaves) from two locations

Figure 4.12: E.coli count in cabbage (outer leaves) from two locations

Figure 4.13: Aerobic bacteria count in cabbage (inner leaves) from two locations

Figure 4.14: Coliform count in cabbage (inner leaves) from two locations

Figure 4.15: E.coli count in cabbage (inner leaves) from two locations

Figure 4.16: Aerobic bacteria count in cabbage (mix leaves) from two locations

Figure 4.17: Coliform count in cabbage (mix leaves) from two locations

Figure 4.18: E.coli count in cabbage (mix leaves) from two locations 


\section{LIST OF TABLES}

Table 2.1: Foodborne disease outbreaks linked to consumption of lettuce and other raw salad vegetables

Table 2.2: Summary of outbreaks and illnesses (2000 to 2007) in the United States associated with cabbage, carrots, celery, and onions

Table 3.1: Lettuce samples collected from different locations

Table 3.2: Cabbage samples collected from different locations

Table 4.1: Microbial contamination of outer leaves from 30 samples of lettuce collected from 2 sources

Table 4.2: Microbial contamination of inner leaves from 30 samples of lettuce collected from 2 sources

Table 4.3: Microbial contamination of Mix (inner \& outer) leaves from 30 samples of lettuce collected from 2 sources

Table 4.4: Microbial contamination of Outer leaves from 30 samples of cabbage collected from 2 sources

Table 4.5: Microbial contamination of inner leaves from 30 samples of cabbage collected from 2 sources

Table 4.6: Microbial contamination of Mix (Outer \& inner) leaves from 30 samples of cabbage collected from 2 sources

Table 4.7: Effect of washing treatment $\&$ disinfection tablet on microbial contamination in Lettuce whole samples collected from super markets

Table 4.8: Effect of washing treatment $\&$ disinfection tablet on microbial contamination in Lettuce whole samples collected from retail markets

Table 4.9: Effect of washing treatment \& disinfection tablet on microbial contamination in cabbage whole samples collected from super markets

Table 4.10: Effect of washing treatment \& disinfection tablet on microbial contamination in cabbage whole samples collected from retail markets 


\section{ACKNOWLEDGEMENTS}

First and foremost I would like to express my deepest gratitude to Prof. KKDS Ranaweera, Director/Bandaranaike Memorial Ayurvedic Research Institute Nawinna, Maharagama, our supervisor, providing valuable feedback and went the extra mile to make helpful changers and suggestions for the manuscript.

I wish to express my thanks to faculty members for their support to complete this report.

I would like to thank the company that I am employed in for allowing me to use the company resources as a foundation for this report.

Finally, I must turn, as we all must ultimately, to my family- that constant source of inspiration. I am grateful for the support of my husband and two children and parents for their love and patience.

Without all of you I would not have been able to make it happen. I wish you peace of mind and happiness. 


\title{
MICROBIAL QUALITY ANALYSIS OF RAW SALAD VEGETBLES
}

\author{
By \\ Lasantha D. Abaynaike
}

\begin{abstract}
Consumption raw salad vegetables has rapidly increased in recent years, but there have also been several reported outbreaks associated with the consumption of these products The study was conducted to investigate the microbial quality of some raw eaten salad vegetables in Jayewardenepura Kotte. Two salad vegetables namely: cabbage (Brassica oleracea) \& lettuce (Lactuca sativa), which were obtained from different markets. A total of 60 samples were analyzed to isolate aerobic bacteria count (APC), coliform bacteria, Escherichia coli, Salmonella and Staphylococcus aureus. The vegetable samples were treated with washing tap water and disinfection tablet which contains sodium dichloroisocyanurate and analysed for aerobic bacteria count (APC), coliform bacteria, Escherichia coli, Salmonella and Staphylococcus aureus. In super market lettuce mean counts of aerobic bacteria were $\log _{10} 5.39,4.80$ and $6.20 \mathrm{cfu} / \mathrm{g}$, mean coliform counts were $\log _{10} 2.61,2.47$ and $2.80 \mathrm{cfu} / \mathrm{g}$, mean E.coli count were $\log _{10} 1.36$, $1.06,1.78 \mathrm{MPN} / \mathrm{g}$ for outer leaves, inner leaves and whole samples, respectively. In retail market lettuce mean counts of aerobic bacteria were $\log _{10} 5.61,4.20$ and $5.77 \mathrm{cfu} / \mathrm{g}$, mean coliform counts were $\log _{10} 2.58,2.46$ and $2.68 \mathrm{cfu} / \mathrm{g}$, mean E.coli counts were $\log _{10} 1.49$, $0.86,1.93 \mathrm{MPN} / \mathrm{g}$ for outer leaves, inner leaves and whole samples, respectively. In super market cabbage mean counts of aerobic bacteria were $\log _{10} 3.72,3.26$ and $4.43 \mathrm{cfu} / \mathrm{g}$, mean coliform counts were $\log _{10} 2.47,2.27$ and $2.59 \mathrm{cfu} / \mathrm{g}$, mean E.coli counts were $\log _{10}$ $1.37,1.07,1.59 \mathrm{MPN} / \mathrm{g}$ for outer leaves, inner leaves and whole samples, respectively. In retail market cabbage mean counts of aerobic bacteria were $\log _{10} 3.53,3.08$ and 4.09 $\mathrm{cfu} / \mathrm{g}$, mean coliform counts were $\log _{10} 2.40,2.14$ and $2.69 \mathrm{cfu} / \mathrm{g}$, mean E.coli counts were $\log _{10} 1.06,0.87,1.34 \mathrm{MPN} / \mathrm{g}$ for outer leaves, inner leaves and whole samples,
\end{abstract}


respectively. Moreover microbial contamination was higher in lettuce samples than in cabbage samples. Salmonella and Staphylococcus aureus were not detected in any of the analyzed samples of the vegetables. Soaking in disinfection tablet was effective against APC, coliform and E.coli.

This study demonstrated that the cabbage and lettuce which are usually consumed as raw salad vegetables contain microorganisms and represent a risk for human health. In conclusion soaking in disinfection reduced the microbial contamination level significantly for safe consumption. Therefore, consumption of these types of vegetables un hygienically paves way for ingestion of considerable numbers of human pathogenic bacteria. 


\section{CHAPTER 1}

\section{INTRODUCTION}

Sri Lanka is a country that having large variety of leaf vegetables \& traditionally consumes a significant amount for meals routinely. Vegetables are any kind of plant product. They refer to the fresh edible portion of herbaceous plant roots, stems, leaves or fruits (Encyclopedia, 1968). Vegetables are mostly annual crops belonging to the group of plants called horticultural crops which are diverse in nature. They can be grouped into fruit and leafy vegetables depending on the nature of their consumable products or parts.

Both types are usually harvested green for human consumption when fresh they have a high water content of about $80 \%$ (N.S.P.R.I, 1992). Living creatures more especially humans depend on vegetables as a source of food for their living. But some of these vegetables inflict economic loss by causing or spreading of human disease after consumption and these affect the health and the progress of the nation. Vegetables possess a high content of minerals and vitamins. According to Mathew (1985), green vegetables are considered as good source of vitamins, minerals such as copper and iron. Their soft textured nature makes them highly attractive to microbial invasion, and they are very susceptible to physical and microbial spoilage. In Sri Lanka leafy salad vegetables which grow together are cabbage (Brassica oleracea) \& lettuce (Lactuca sativa). In Sri Lankan context lettuce is not cultivated as a monocrop. It is always mixed with crops like cabbages. Lettuces of various varieties are frequently the main component of the fresh cut products, but other ingredients may include capsicum (green pepper), carrots, cabbage and celery (Nguyen- the \& Carlin 2000). Consumer demands for healthy convenient "life style" food have led to a rapid worldwide growth in markets for these products.

The increased popularity of fresh vegetables has focused greater attention on their quality and factors that affect this quality. Microorganisms have a significant role in this context. The shelf life of ready to eat salads is generally about $7-14$ days at $5^{\circ} \mathrm{C}$, being limited by endogenous biochemical and physiological changes in the produce, and the growth of spoilage 
microorganisms. Because these products are only minimally processed and consumed in the fresh state, they have increased risk with respect to public health. In recent years, numerous outbreaks of gastrointestinal illness have been linked to their consumption and contamination with bacterial pathogens (Garcia-Gimeno and Zurera-Cosano 1997). A comprehensive understanding of the microbial ecology of vegetable produce and the factor that lead to their contamination with microorganisms is needed for effective management of their quality and safety.

The Sri Lanka Export Development Board along with the Sri Lanka National Chamber of Commerce has launched a project to grow Iceberg Lettuce in Poly-green Houses in the Nuwara Eliya District. The objectives of the project are to improve quality and productivity, Sustainable livelihood development of the people in the area, to encourage people for self-employment, improve profitability of the venture, and to acquire standards required for the International Market. (Daily Mirror, 2008).

In Sri Lankan context lettuce is not cultivated as a monocrop. It is always mixed with crops like cabbages. So author studied cabbage and lettuce vegetables because of its prominent position as a component of ready-to-eat salad products.

\section{Objectives}

1. Investigate microbial contamination in lettuce samples collected from different markets.

2. Investigate microbial contamination in cabbage samples collected from different markets.

3. Investigate the effect of microbial load in the vegetables by washing with tap water \& disinfectant tablets. 


\section{CHAPTER 2}

\section{LITERATURE REVIEW}

\subsection{WORLD VEGETABLE INDUSTRY}

During the last years, the consumption of fresh vegetables has been increasing as consumers strive to eat healthy diets and the availability of these produce, up till recently considered as seasonal, has been extended over the whole year.

Fresh salad vegetables are minimally processed by washing, slicing, dicing, peeling and shredding prior to sale. In Sri Lanka leafy salad vegetables which grow together are lettuce and cabbage. Raw vegetables can harbour many microorganisms, which may be dispersed over the plant or appear as micro colonies embedded in the plant tissue (Szabo \& Coventry, 2001). The majority of microorganisms associated with raw vegetables are non-pathogenic and gram negative organisms tend to dominate the bacterial population including Enterobacter spp. and other coliforms. During harvest and transport raw vegetables may be bruised resulting in the release of plant nutrients, providing nutrients for microorganisms present on the surface of the vegetable to grow. The processing of fresh cut vegetables by slicing, dicing and shredding has little effects on the vegetables' tissues; however these processes may alter or increase the number and type of microorganisms present on the surface of the product. Washing in sanitized water is sometimes used to assist in reducing the number of microorganisms present. In addition, some fresh cut vegetables are packaged under modified atmosphere packaging (MAP) and refrigerated to extend the shelf life. With additional timeframe this creates, there is an increased risk from pathogens that are able to survive and grow in these foods. (Beuchat, 2002)

The importance of bacterial pathogens in the transmission of foodborne illness has become apparent in recent years. Several large, well-publicized outbreaks of foodborne illness have been linked to cantaloupe, tomatoes, lettuce, alfalfa sprouts, and both apple and orange juices. Control of foodborne pathogens in produce must begin before produce is even planted by avoiding fields which have been subjected to flooding, on which animals have been recently 
grazed, or have otherwise been contaminated with manure. Both field workers and packinghouse and processing plant personnel should be instructed in proper personal hygiene and provided with adequate sanitary and hand washing facilities. Vehicles transporting finished products should be sanitized, properly loaded to provide adequate air circulation, and maintained at proper temperatures.

\subsection{CABBAGE \& LETTUCE}

Cabbage (Brassica oleracea) is believed to have evolved from a wild form native to Europe, growing along the coast of the North Sea, the English Channel and northern Mediterranean. In $350 \mathrm{BC}$ cabbage was described and the Greeks cultivated it as early as $600 \mathrm{BC}$ and they believed that cabbage was a gift from the gods. Ancient Rome it was reported as a softheaded form and the Saxons and Romans probably cultivated it and introduced it to the British Isles. The hardheaded types were only mentioned in the 9th century. The early Egyptians are said to have worshipped it.

Annual world production is about 21 million tones of fresh heads from 1.1 million hectares. In Sri Lanka cabbage is one of the important vegetable is cultivated in large extent mainly in the up-country as a year round crop. In the low country it is only during Maha season. Among the other vegetables cabbage is one of the easiest crop to established and manage thus most of the people grow this crop in their home gardens. It is also an important economical and rotational crop in the major vegetable growing areas.

The plant was used for medicinal purposes to treat gout, stomach problems, deafness, headache and hangovers in the early days. Cabbage is now grown throughout the world.

The lettuce (Lactuca sativa) is an annual plant of the aster or sunflower family Asteraceae. It is most often grown as a leaf vegetable, but also sometimes for its stem and seeds. It is one of the most important vegetable crops in the world. Lettuce was first cultivated by the ancient Egyptians, who turned it from a weed whose seeds were used to make oil into a plant grown for its leaves. Lettuce is easily cultivated, although it requires relatively low temperatures 